\title{
EDITORIAL
}

\section{Time to Do the Right Thing: End Fee-for-Service for Primary Care}

\author{
Michael K. Magill, MD \\ Department of Family and Preventive Medicine, University of Utah School of Medicine, Salt Lake City, Utah \\ Ann Fam Med 2016;14:400-401. doi: 10.1370/afm.1977.
}

You can always count on Americans to do the right thing after they've tried everything else.

\section{-Winston Churchill}

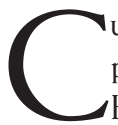
urrent fee-for-service (FFS) payment rates for physician visits trace to the origins of Blue Cross Blue Shield insurance in the 1930s. At that time, rates were set that paid generously for hospitalizations and for procedures, such as surgery., ${ }^{1,2}$ Payments for socalled "cognitive services" were lower per minute of physician time. This disparity has been perpetuated since the 1980s in the calculation of rates set by the Centers for Medicare \& Medicaid Services (CMS), based on "Relative Value Units," for payment of the Evaluation and Management codes most often billed by primary care physicians. ${ }^{3}$ Despite recognition by the Medicare Payment Advisory Commission (MedPAC) ${ }^{4}$ and others ${ }^{5}$ of the adverse effects of inadequate payment for primary care, only limited progress has been made toward correction of the disparity. This may be due, at least in part, to treatment of total payment for physicians as a zerosum game in which decision making is dominated by non-primary care physicians through mechanisms such as the Relative Value Scale Update Committee (RUC). ${ }^{6,7}$

Although in the United States we are most familiar with this fee-for-service payment arrangement, it is a creation of man, not nature. And even in this country, other models have existed since at least the mid-20th century. Most prominent of these others is the capitated payment model pioneered by Kaiser Permanente

Conflict of interest: author reports none.

\section{CORRESPONDING AUTHOR}

Michael K. Magill, MD

Professor and Chairman

Department of Family and Preventive Medicine

University of Utah School of Medicine

375 Chipeta Way, Suite A

Salt Lake City, UT 84108

michael.magill@hsc.utah.edu beginning in $1945^{8}$ and expanded in the Health Maintenance Organizations (HMOs) of the 1980s and 1990s. ${ }^{9}$ Following collapse of many of the HMOs, payers have experimented with multiple smaller changes in payment models, mostly incremental adjustments to existing FFS, perpetuating structural disadvantages for primary care.

In this issue of the Annals, Basu, et al report on their study in which they calculated potential effects on primary care practice costs and revenue resulting from 3 modifications of FFS payment: increased FFS, traditional FFS plus per-member per-month (PMPM), and traditional FFS plus PMPM plus pay-for-performance (P4P). ${ }^{10}$ The authors drew on extensive published literature about how primary care practices can staff and organize to deliver patient-centered medical home (PCMH) services such as enhanced access, care management, and alternative visits, and the impact of these changes on revenue and expense within the practices. The authors created simulated models of these financial effects based on detailed profiles of patient demographics, insurance coverage, and disease burden. They conducted tens of thousands of iterations to determine results assuming random variations within expected ranges, and sensitivity of their results to reasonable variations in assumptions, such as about payment amounts.

This was an extraordinary project, impossible to conduct as an experiment in real life due to the huge number of variables considered and number of iterations possible in the simulation environment. The findings are granular, robust, and convincing: none of the payment strategies considered provides sufficient support for primary care practice transformation beyond the minimum needed to meet PCMH criteria. And meeting minimum criteria is not the same thing as actually transforming care to improve quality and reduce cost. ${ }^{11}$

The authors report their results in exhaustive detail, including extensive online appendixes. If each data point in their results is 1 grain of sand, together they form an arid desert, one which the shallow wells of 
modified FFS cannot turn into blooming oases. As the authors dryly conclude, "Achieving goals of the PCMH will likely require more radical payment reforms to specifically target funding towards the delivery of desired services." ${ }^{\prime 10}$ Bluntly put: tweaking FFS payment will not save health care.

Although this is a seminal and powerful paper, the simulations do not address all possible futures. Rather, they only extrapolate from the present, and PCMH service models are sure to evolve over time. That said, the authors have developed a methodology that can be applied to future payment and practice models and incorporate new data as it becomes available. In addition to, for example, extended interdisciplinary teams in primary care, these might include effects of new value-based payment models such as the CMS Merit Based Incentive Payment System (MIPS), Alternative Payment Models (APMs), ${ }^{12}$ Next Generation ACOs, Shared Savings, ${ }^{13}$ and Direct Primary Care (DPC). ${ }^{14}$

Future applications should go beyond assessing payment effects on revenues and expense within the PCMH alone to address effects on total cost of care. This is because the financial benefits, if any, of advanced primary care such as PCMHs, accrue not within the practice itself but as a result of "downstream" savings such as from reduced emergency department visits and hospital admissions. ${ }^{15,16}$ Achieving the benefits of overall care redesign will require new payment models that reward primary care practices for results across the full continuum of care, not simply pay for services provided within the primary care practice itself.

This report provides ample evidence for a simple truth: it is time to end FFS payment for primary care. ${ }^{17}$ The paper puts a very large nail in the coffin for failed models of payment based on FFS. We have tried everything else. It is time for America to do the right thing and implement comprehensive payment for primary care that rewards physicians and their colleagues, not just for providing "desired services," but for achieving the Quadruple Aim of better care, lower cost, better health, and clinician satisfaction. ${ }^{18}$ This will enable a system that is incredibly attractive and satisfying to teams of skilled professionals working together. It can become one that is financially sustainable, not just for primary care practices but for American health care, for our communities, and for our patients.

To read or post commentaries in response to this article, see it online at http://www.annfammed.org/content/14/5/400.

Submitted August 2, 2016; submitted, revised, August 2, 2016; accepted August 2, 2016.

Acknowledgement: Isabella Alder, MPH, provided research and editorial assistance in preparation of this editorial.

\section{References}

1. Cunningham R III, Cunningham RM. The Blues: A History of the Blue Cross and Blue Shield System. DeKalb, Ill: Northern Illinois University Press; 1997.

2. O'Shea J. Individual and social concerns in American surgical education: paying patients, prepaid health insurance, Medicare and Medicaid. Acad Med. 2010;85(5):854-862. Accessed Jun 8, 2016.

3. Laugesen M, Wada R, Chen E. In setting doctors' Medicare fees, CMS almost always accepts the Relative Value Update Panel's advice on work values. Health Aff (Millwood). 2012;31(5):965-972.

4. Medicare Payment Advisory Commission. Report to the Congress: Medicare Payment Policy. http://medpac.gov/documents/reports/ mar14_entirereport.pdf. Published Mar 14, 2014. Accessed Jun 13, 2016.

5. Bodenheimer T, Berenson RA, Rudolf P. The primary care-specialty income gap: why it matters. Ann Intern Med. 2007;146(4):301-306.

6. The RVS Update Committee. American Medical Association Web site. http://www.ama-assn.org/ama/pub/physician-resources/ solutions-managing-your-practice/coding-billing-insurance/ medicare/the-resource-based-relative-value-scale/the-rvs-updatecommittee.page. Accessed Jun 13, 2016.

7. Relative Value Scale Update Committee (RUC). American Academy of Family Physicians Web site. http://www.aafp.org/practicemanagement/payment/ruc.html. Accessed Jun 13, 2016.

8. Strandberg-Larsen M, Schiøtz M, Hsu J, et al. Is the Kaiser Permanente model superior in terms of clinical integration? A comparative study of Kaiser Permanente, Northern California and the Danish healthcare system. BMC Health Serv Res. 2010;10:91-103 http://www. ncbi.nlm.nih.gov/pmc/articles/PMC2907761/. Accessed Jun 9, 2016.

9. Zuvekas S, Cohen J. Paying physicians by capitation: is the past now prologue?. Health Aff (Millwood). 2010;29(9):1661-1666.

10. Basu S, et al. Effects of new funding models for patient-centered medical homes on primary care practice finances and services: results of a microsimulation model. Ann Fam Med. 2016;14(5):404-414.

11. Lukas C, Holmes S, Charns M, et al. Transformational change in health care systems: an organizational model. Health Care Manage Rev. 2007;32(4):309-320. Accessed Jun 10, 2016.

12. Porter S. AAFP expends huge effort to shape new payment system. Ann Fam Med 2016;14(1):84-85. http://www.annfammed.org/ content/14/1/84.full. Accessed Jun 10, 2016.

13. Siddiqui M, Berkowitz S. Shared savings models for ACOs-incentivizing primary care physicians. J Gene Intern Med. 2014;29(6):832-834. http://www.ncbi.nlm.nih.gov/pmc/articles/PMC4026515/. Accessed Jun 10, 2016.

14. Huff C. Direct primary care: concierge care for the masses. Health Aff (Millwood). 2015;34(12):2016-2019. http://content.healthaffairs. org/content/34/12/2016.abstract. Accessed Jun 10, 2016.

15. Grumbach K, Bodenheimer T, Grundy P. The outcomes of implementing patient-centered medical home interventions. 2009. http://pcmh.ahrq.gov/sites/default/files/attachments/The $\% 20$ Outcomes $\% 20$ of\%20Implementing\%20PatientCentered\%20 Medical\%20Home\%2OInterventions.pdf. Accessed Aug 26, 2014.

16. Maeng D, Khan N, Tomcavage J, Graf T, Davis D, Steele G. Primary care: reduced acute inpatient care was largest savings component of Geisinger Health System's patient-centered medical home. Health Aff (Millwood). 2015;34(4):636-644.

17. Phillips Jr R, Pugno P, Puffer J, et al. Health is primary: family medicine for America's health. Ann Fam Med. 2014;12:S1-S12. http:// www.annfammed.org/content/12/Suppl_1/S1.full. Accessed June 9, 2016.

18. Bodenheimer T, Sinsky C. From triple to quadruple aim: care of the patient requires care of the provider. Ann Fam Med. 2014;12(6):573576. http://www.annfammed.org/content/12/6/573.full. Accessed June 9, 2016. 